\title{
Phyllobacterium catacumbae sp. nov., a member of the order 'Rhizobiales' isolated from Roman catacombs
}

\author{
V. Jurado, ${ }^{1}$ L. Laiz, ${ }^{1}$ J. M. Gonzalez, ${ }^{1}$ M. Hernandez-Marine, ${ }^{2}$ M. Valens ${ }^{3}$ \\ and C. Saiz-Jimenez ${ }^{1}$ \\ ${ }^{1}$ Instituto de Recursos Naturales y Agrobiologia, CSIC, Apartado 1052, 41080 Sevilla, Spain \\ ${ }^{2}$ Departament de Productes Naturals, Biologia Vegetal i Edafologia, Universitat de Barcelona, \\ 08028 Barcelona, Spain \\ ${ }^{3} \mathrm{GOI}$, Institut Mediterràni d'Estudis Avançats (CSIC-UIB), Miquel Marqués 21, 07190 Esporles, \\ Illes Balears, Spain
}

\begin{abstract}
Two strains were isolated from tuff, a volcanic rock that forms the walls of the Roman Catacombs of Saint Callixtus in Rome, Italy. A polyphasic approach using nutritional and physiological tests, reactions to antibiotics, fatty acid profiles, DNA base ratios, DNA-DNA reassociation and 16S rRNA gene sequence comparisons showed that the two isolates belong to a novel species within the genus Phyllobacterium. The species Phyllobacterium catacumbae sp. nov. is proposed. The type strain is $\mathrm{CSC}_{19^{\top}}\left(=\mathrm{CECT} 5680^{\top}=\mathrm{LMG} 22520^{\top}\right)$.
\end{abstract}

The genus Phyllobacterium was described by Knösel (1962), who defined two species, Phyllobacterium myrsinacearum and Phyllobacterium rubiacearum, isolated from leaf nodules of tropical ornamental plants (myrsine and madder, respectively). Both species were described and differentiated on the basis of phenotypic features. The genus name was not included in the Approved Lists (Skerman et al., 1980) but was revived in the first edition of Bergey's Manual of Systematic Bacteriology by Knösel (1984a) and subsequently validly published (Knösel, 1984b). Based on fatty acid compositions and DNA-DNA hybridization, Mergaert et al. (2002) proposed that $P$. rubiacearum was a later heterotypic synonym of $P$. myrsinacearum.

This paper reports the isolation of two strains, $\operatorname{CSC} 19^{\mathrm{T}}$ $\left(=\mathrm{LMG} 22520^{\mathrm{T}}=\mathrm{CECT} 5680^{\mathrm{T}}\right)$ and CSC32 $(=\mathrm{LMG}$ $22521=$ CECT 5681), from tuff, a volcanic rock that forms the walls of the Roman Catacombs of Saint Callixtus in Rome, Italy. A polyphasic approach showed that these isolates belong to a novel species within the genus Phyllobacterium.

Strains $\mathrm{CSC} 19^{\mathrm{T}}$ and CSC32 were isolated in B-4 medium composed (per litre) of $2.5 \mathrm{~g}$ calcium acetate, $4 \mathrm{~g}$ yeast extract and $15 \mathrm{~g}$ agar, pH 8 (Boquet et al., 1973). Cultures were incubated at $28^{\circ} \mathrm{C}$. Morphological studies were carried out from cultures on tryptose soy agar (TSA; Oxoid). Wet slide suspensions of cultures grown in tryptose soy broth

The GenBank/EMBL/DDBJ accession numbers for the partial $16 \mathrm{~S}$ rRNA gene sequences of $P$. catacumbae strains CSC32 and CSC $19^{\top}$ are respectively AY635999 and AY636000.
(Oxoid) were observed by phase contrast microscopy. Acid production from a variety of substrates was tested using the API $50 \mathrm{CH} \mathrm{B/E} \mathrm{kit} \mathrm{(bioMérieux)} \mathrm{and} \mathrm{assimilation} \mathrm{tests}$ were carried out using the API 20 NE kit (bioMérieux); API tests were performed according to the manufacturer's instructions. Nitrate reduction, catalase and hydrogen sulfide production, hydrolysis of Tweens 20 and 80, methyl red and Voges-Proskauer reactions were tested according to Lanyi (1987). Indole production (Smibert \& Krieg, 1994), hydrolysis of starch (Cowan \& Steel, 1965), 3-ketolactose (Bernaerts \& De Ley, 1963) and DNase activities (SotoHernandez et al., 1988) were also tested. Oxygen requirement for growth was studied using a GENbag Anaer incubation system (bioMérieux). Susceptibility to antibiotics was studied by placing antibiotic discs (Mast Diagnostics) on TSA plates inoculated with suspensions of the test strains. Oxidase activity was studied by monitoring the oxidation on dryslide oxidase (Becton Dickinson). For the Gram reaction, a $3 \%$ solution of potassium hydroxide was used (Halebian et al., 1981). Flagella were stained with flagella stain droppers (Becton Dickinson). $\mathrm{N}_{2}$ fixation was evaluated as a growth response in minimal medium composed (per litre) of: $0.5 \mathrm{~g} \mathrm{CaCl}_{2} .2 \mathrm{H}_{2} \mathrm{O}, 0.5 \mathrm{~g} \mathrm{~K}_{2} \mathrm{HPO}_{4}, 0.2 \mathrm{~g}$ $\mathrm{MgSO}_{4} \cdot 7 \mathrm{H}_{2} \mathrm{O}, 0 \cdot 2 \mathrm{~g} \mathrm{NaCl}, 0 \cdot 1 \mathrm{~g} \mathrm{FeCl}_{3}, 10 \mathrm{ml}$ trace element solution (Balch et al., 1979) and $0 \cdot 5 \mathrm{~g}$ sucrose, $\mathrm{pH} 6 \cdot 8-7 \cdot 0$. Cultures were prepared in the presence and absence of ammonium $\left(0 \cdot 25 \mathrm{~g} \mathrm{NH}_{4} \mathrm{Cl} \mathrm{l}^{-1}\right)$. A medium without ammonium was inoculated with the different strains and $1 \mathrm{ml}$ was transferred to fresh medium both in the absence and presence of ammonium. Repeated transfers in ammonium-deficient medium revealed the inability of 
strains $\mathrm{CSC} 19^{\mathrm{T}}$ and $\mathrm{CSC} 32$, as well as the P. myrsinacearum type strain, to grow in the absence of ammonium. Morphological, physiological and biochemical traits are summarized in the species description and Table 1.

Cellular fatty acid profiles were analysed following standard methods described by Gonzalez et al. (2004). The predominant fatty acids $(>5 \%)$ of strains $\operatorname{CSC} 19^{\mathrm{T}}$ and $\operatorname{CSC} 32$ are shown in Table 2. The major fatty acid in $P$. myrsinacearum was $18: 1 \omega 7 c$ (Mergaert et al., 2002), as in strains $\mathrm{CSC}_{19}{ }^{\mathrm{T}}$ and CSC32. Fatty acid 11-methyl $18: 1 \omega 7 c$ was a minor constituent $(2.3 \%)$ in P. myrsinacearum.

Bacterial DNA was extracted following the method described by Marmur (1961). The 16S rRNA gene was amplified by PCR using the conserved primers 27F (5'AGAGTTTGATCCTGGCTCAG) and 1522R (5'-AAGGAGGTGATCCAGCCGCA). PCR thermal conditions were as follows: $95^{\circ} \mathrm{C}$ for $1 \mathrm{~min} ; 35$ cycles of $95^{\circ} \mathrm{C}$ for $15 \mathrm{~s}, 55^{\circ} \mathrm{C}$ for $15 \mathrm{~s}, 72{ }^{\circ} \mathrm{C}$ for $2 \mathrm{~min}$; and a final extension cycle at $72^{\circ} \mathrm{C}$ for $10 \mathrm{~min}$. Forward and reverse strands of the amplified DNA fragment were sequenced in an ABI 3700 sequencer

Table 1. Phenotypic characteristics of strains $\operatorname{CSC} 19^{\top}$, CSC 32 and P. myrsinacearum

Taxa: 1, P. myrsinacearum; 2, strain $\mathrm{CSC}_{19} 9^{\mathrm{T}} ; 3$, strain CSC32. All three taxa bear polar, subpolar or lateral flagella, stain negative in the Gram reaction and do not grow in the presence of $2 \% \mathrm{NaCl}$. P. catacumbae strains $\mathrm{CSC} 19^{\mathrm{T}}$ and $\mathrm{CSC} 32$ are negative for hydrolysis of $\beta$-galactoside, gelatin, 3-ketolactose, starch and Tweens 20 and 80 . They are positive for the hydrolysis of arginine, $\beta$-glucoside and urea. They are positive for the production of hydrogen sulfide. Catalase and oxidase tests give positive results. Voges-Proskauer, methyl red and indole tests give negative results. DNase activity is negative. They are susceptible to doxycycline $(30 \mu \mathrm{g})$, fragmycetin $(50 \mu \mathrm{g})$, novobiocin $(30 \mu \mathrm{g})$ and tetracycline $(30 \mu \mathrm{g})$ and resistant to streptomycin $(10 \mu \mathrm{g})$. - , Negative; + , positive; $(+)$ weakly positive.

\begin{tabular}{|lccc|}
\hline Characteristic & $\mathbf{1}$ & $\mathbf{2}$ & $\mathbf{3}$ \\
\hline Nitrate reduction & $+^{*}$ & - & - \\
Acid production (API $50 \mathrm{CH}$ B/E) from: & & & \\
D-Adonitol & $+^{*}$ & - & - \\
Dulcitol & $+^{*}$ & - & - \\
Erythritol & - & + & + \\
Glycerol & $+^{\star}$ & - & - \\
Lactose & - & + & $(+)$ \\
Methyl $\alpha$-D-glucopyranoside & + & - & - \\
N-Acetylglucosamine & - & + & + \\
L-Sorbose & + & - & - \\
D-Tagatose & + & - & - \\
Xylitol & + & - & - \\
Assimilation (API 20 NE) of: & & & \\
Trisodium citrate & + & - & - \\
\hline
\end{tabular}

${ }^{\star}$ Data from Mergaert et al. (2002).
Table 2. Comparison of the major fatty acids found in $P$. myrsinacearum and strains $\mathrm{CSC}_{1} 9^{\top}$ and CSC32

Taxa: 1, P. myrsinacearum; 2, strain $\mathrm{CSC}^{9^{\mathrm{T}}}$; 3, strain CSC32. Values represent percentages of total fatty acid content and standard deviations are showed in parentheses. Data for P. myrsinacearum were taken from Mergaert et al. (2002). ND, Not detected.

\begin{tabular}{|lccr|}
\hline Fatty acid & $\mathbf{1}$ & $\mathbf{2}$ & $\mathbf{3}$ \\
\hline $16: 0$ & $6 \cdot 0-9 \cdot 1$ & $16 \cdot 0(0 \cdot 3)$ & $16 \cdot 9(0 \cdot 8)$ \\
$16: 03-\mathrm{OH}$ & $5 \cdot 4-5 \cdot 7$ & $0 \cdot 5(0 \cdot 0)$ & $0 \cdot 5(0 \cdot 0)$ \\
$17: 0$ cyclo & $\mathrm{ND}$ & $1 \cdot 1(0 \cdot 1)$ & $1 \cdot 3(0 \cdot 1)$ \\
$17: 0$ & $\mathrm{ND}$ & $1 \cdot 1(0 \cdot 2)$ & $1 \cdot 8(0 \cdot 0)$ \\
$18: 1 \omega 7 c$ & $61 \cdot 0-64 \cdot 9$ & $47 \cdot 9(2 \cdot 7)$ & $44 \cdot 2(1 \cdot 8)$ \\
$18: 0$ & $\mathrm{ND}-3 \cdot 3$ & $2 \cdot 4(0 \cdot 1)$ & $2 \cdot 1(0 \cdot 2)$ \\
$11-$ methyl $18: 1 \omega 7 c$ & $\mathrm{ND}-2 \cdot 3$ & $10 \cdot 6(0 \cdot 7)$ & $11 \cdot 2(1 \cdot 0)$ \\
$19: 0$ cyclo $\omega 8 c$ & $4 \cdot 8-6 \cdot 2$ & $13 \cdot 7(1 \cdot 3)$ & $15 \cdot 0(1 \cdot 9)$ \\
$18: 12-\mathrm{OH}$ & $4 \cdot 5-5 \cdot 2$ & $\mathrm{ND}$ & $\mathrm{ND}$ \\
$20: 0$ & $3 \cdot 7-4 \cdot 4$ & $\mathrm{ND}$ & $\mathrm{ND}$ \\
& & & \\
\hline
\end{tabular}

(Applied Biosystems). A homology search was performed using the BLAST algorithm (Altschul et al., 1990) at NCBI (National Centre for Biotechnology Information; http://www.ncbi.nlm.nih.gov/). Sequence alignment was performed using the software suite ARB (Ludwig et al., 2004). The alignment was manually edited considering the expected sequence secondary structure. An unrooted phylogenetic tree was constructed by maximum-likelihood using the program fastDNAmL (Felsenstein, 1981) embedded in ARB. The obtained tree topology was reconstructed by quartet-puzzling using the program Treepuzzle (Strimmer \& von Haeseler, 1996) also available in the ARB package. The quartet-puzzling tree represented a consensus tree showing well-supported branching. It was based on 1000 puzzling trials. The reliability value of each internal branch indicates as a percentage how often the corresponding cluster was found. Comparisons of $16 \mathrm{~S}$ rRNA gene sequences from strains $\operatorname{CSC} 19^{\mathrm{T}}$ and CSC 32 revealed similarities of $97 \cdot 4$ and $97 \cdot 2 \%$ with P. myrsinacearum strains DSM $5892^{\mathrm{T}}$ and DSM 5893, respectively. A phylogenetic tree showing the relationships between $P$. myrsinacearum, isolates $\operatorname{CSC} 19^{\mathrm{T}}$ and CSC32 and members of closely related genera is shown in Fig. 1.

The $\mathrm{G}+\mathrm{C}$ content of genomic DNA was determined following the fluorimetric method described by Gonzalez \& Saiz-Jimenez (2002) using the thermal denaturation temperature. The DNA G $+\mathrm{C}$ contents of strains $\mathrm{CSC} 19^{\mathrm{T}}$ and CSC32 were $55 \cdot 9 \pm 0 \cdot 4$ and $53 \cdot 8 \pm 0 \cdot 6 \mathrm{~mol} \%$, respectively. These values are slightly lower than the proposed for the emended species P. myrsinacearum, $60 \cdot 3-61 \cdot 3 \mathrm{~mol} \%$ (Mergaert et al., 2002).

The degree of DNA-DNA relatedness between the two isolates and P. myrsinacearum was determined by two independent methods: the DNA-DNA hybridization method described by Ziemke et al. (1998) and by measuring 


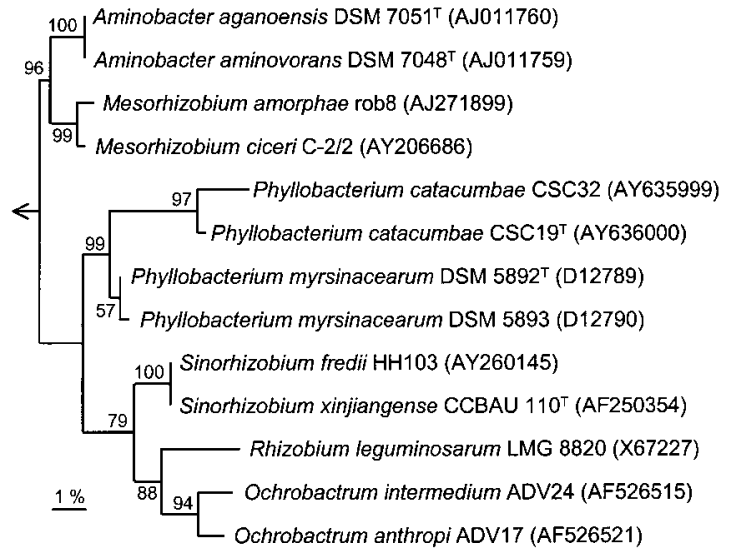

Fig. 1. Phylogenetic tree showing the relationships between $P$. myrsinacearum, strains $\mathrm{CSC}_{1} 9^{\top}$ and $\mathrm{CSC} 32$ proposed as $P$. catacumbae, and members of closely related genera. Reliability values are given at branching points as percentages from 1000 trials. Strain name and accession number for the strains represented in the tree are shown in parentheses. Escherichia coli O157:H7 (GenBank accession no. AY513502) was used as the outgroup.

the divergence between the thermal denaturation midpoint of homoduplex DNA and heteroduplex DNA $\left(\Delta T_{\mathrm{m}}\right)$ as described by Gonzalez \& Saiz-Jimenez (2005). Strains $\mathrm{CSC}_{19}{ }^{\mathrm{T}}$ and CSC32 showed $100 \%$ DNA-DNA hybridization and no significant $\Delta T_{\mathrm{m}}$ was observed. However, the hybridization between $\mathrm{CSC}_{1} 9^{\mathrm{T}}$ and P. myrsinacearum DSM $5892^{\mathrm{T}}$ was $43.4 \%$ and the two strains showed a $\Delta T_{\mathrm{m}}$ of $>9{ }^{\circ} \mathrm{C}$ (equivalent to $<45 \%$ hybridization as proposed by Rosselló-Mora \& Amann, 2001). Altogether, these results indicate that both strains show sufficient genomic coherence and sufficient hybridization differences from their closest relatives to be considered as a single species (Rosselló-Mora \& Amann, 2001; Stackebrandt et al., 2002).

The two strains under study derived from the same hypogean environment, the Roman Catacombs of Saint Callixtus. A polyphasic approach, considering both genotypic and phenotypic characteristics, suggests a divergent classification of strains $\mathrm{CSC} 19^{\mathrm{T}}$ and CSC 32 within the genus Phyllobacterium (Lambert et al., 1990). On this basis, we propose a novel species, Phyllobacterium catacumbae sp. nov. comprising two strains, $\mathrm{CSC} 19^{\mathrm{T}}$ and CSC32.

Members of the genus Phyllobacterium were described as the second most frequently occurring bacteria on root surfaces during a large-scale assessment of the rhizobacterial communities of young sugar beet plants. Extensive analyses of the microflora from the rhizoplane of other crop plants did not reveal the presence of strains of Phyllobacterium (Lambert et al., 1990). This paper describes a novel species, P. catacumbae, inhabiting the walls of Roman catacombs. This novel species occupies a completely different niche and poses some questions about the relationship of members of the genus Phyllobacterium with plants.

\section{Description of Phyllobacterium catacumbae sp. nov.}

Phyllobacterium catacumbae (ca.ta.cum'bae. L. gen. n. catacumbae of catacombs).

Gram-negative, aerobic cells, motile by a polar tuft of flagella. Colonies are circular, smooth and beige with a colony diameter of less than $1 \mathrm{~mm}$ after 2 days of incubation; after 6 days, colonies reach a maximum diameter of $4 \mathrm{~mm}$. Cells are short rods, $0 \cdot 4-1.9 \mu \mathrm{m}$ long and $0 \cdot 4-$ $0 \cdot 7 \mu \mathrm{m}$ wide, in exponential growth. Optimum temperature for growth is $28^{\circ} \mathrm{C}$. Phenotypic characteristics including antibiotic susceptibility are shown in Table 1. In addition, acid is produced from DL-arabinose, D-cellobiose, aesculin, D-fructose, DL-fucose, D-galactose, D-glucose, inositol, D-lyxose, D-maltose, D-mannitol, D-mannose, D-melibiose, $\mathrm{N}$-acetylglucosamine, L-rhamnose, D-ribose, D-sucrose, D-sorbitol, D-trehalose, D-turanose and DL-xylose. Glucose, arabinose, mannose, mannitol, $\mathrm{N}$ acetylglucosamine, maltose, potassium gluconate and malate are assimilated. Predominant fatty acids are $18: 1 \omega 7 c, 16: 0,19: 0$ cyclo $\omega 8 c$ and 11-methyl $18: 1 \omega 7 c$. The DNA G + C content is $55 \cdot 9 \pm 0 \cdot 4 \mathrm{~mol} \%$.

The type strain is $\operatorname{CSC} 19^{\mathrm{T}}\left(=\mathrm{CECT} 5680^{\mathrm{T}}=\mathrm{LMG} 22520^{\mathrm{T}}\right)$. The organism was isolated from the tuff walls of the Roman catacombs of Saint Callixtus, Rome, Italy.

\section{Emended description of the genus Phyllobacterium (ex Knösel 1962) Knösel 1984}

The description is as given by Knösel (1984a) with the following modifications. Acid production from adonitol, dulcitol and glycerol is variable. Members of the genus Phyllobacterium are not restricted to tropical leaf nodules but can also be present in hypogean environments. The DNA G + C content ranges from $53 \cdot 8$ to $61 \cdot 3 \mathrm{~mol} \%$. The type species is Phyllobacterium myrsinacearum. The genus includes two species, $P$. myrsinacearum (heterotypic synonym $P$. rubiacearum) and $P$. catacumbae.

\section{Acknowledgements}

V.J. and L.L. received fellowships from the Spanish Ministry of Education and Science (MEC), I3P programme and J.M.G. is supported by an MEC contract from the 'Ramón y Cajal' program. This study was supported by EC project EVK4-CT2000-00028 and MEC project BTE2002-04492-C02-01. The authors acknowledge the collaboration of R. Rosselló-Mora.

\section{References}

Altschul, S. F., Gish, W., Miller, W., Myers, E. W. \& Lipman, D. J. (1990). Basic local alignment search tool. J Mol Biol 215, 403-410.

Balch, W. E., Fox, G. E., Magrum, L. J., Woese, C. R. \& Wolfe, R. S. (1979). Methanogens: reevaluation of a unique biological group. Microbiol Rev 43, 260-296. 
Bernaerts, M. J. \& De Ley, J. (1963). A biochemical test for crown gall bacteria. Nature 197, 406-407.

Boquet, E., Bordonat, A. \& Ramos Cormenzana, A. (1973). Production of calcite crystals by soil bacteria is a general phenomenon. Nature 246, 527-528.

Cowan, S. T. \& Steel, K. J. (1965). Manual for the Identification of Medical Bacteria. Cambridge: Cambridge University Press.

Felsenstein, J. (1981). Evolutionary trees from DNA sequences: a maximum likelihood approach. J Mol Evol 17, 368-376.

Gonzalez, J. M. \& Saiz-Jimenez, C. (2002). A fluorimetric method for the estimation of $\mathrm{G}+\mathrm{C}$ mol\% content in microorganisms by thermal denaturation temperature. Environ Microbiol 4, 770-773.

Gonzalez, J. M. \& Saiz-Jimenez, C. (2005). A simple fluorimetric method for the estimation of DNA-DNA relatedness between closely related microorganisms by thermal denaturation temperatures. Extremophiles 9, 75-79.

Gonzalez, J. M., Jurado, V., Laiz, L., Zimmermann, J., Hermosin, B. \& Saiz-Jimenez, C. (2004). Pectinatus portalensis nov. sp., a relatively fast-growing, coccoidal, novel Pectinatus species isolated from a wastewater treatment plant. Antonie van Leeuwenhoek 86, 241-247.

Halebian, S., Harris, B., Finegold, S. M. \& Rolfe, R. D. (1981). Rapid method that aids in distinguishing Gram-positive from Gramnegative anaerobic bacteria. J Clin Microbiol 13, 444-448.

Knösel, D. (1962). Prüfung von bakterien auf fähigkeit zur sternbildung. Zentralbl Bakteriol Parasitenkd Infektionskr Hyg II Abt 116, 79-100 (in German).

Knösel, D. (1984a). Genus IV Phyllobacterium (ex Knösel 1962) nom. rev. (Phyllobacterium Knösel 1962, 96). In Bergey's Manual of Systematic Bacteriology, vol. 1, pp. 254-256. Edited by N. R. Krieg \& J. G. Holt. Baltimore: Williams \& Wilkins.

Knösel, D. (1984b). Genus Phyllobacterium nom. rev. In Validation of the Publication of New Names and New Combinations Previously Effectively Published Outside the IJSB, List no. 15. Int J Syst Bacteriol 34, 355-357.
Lambert, B., Joos, H., Dierickx, S., Vantomme, R., Swings, J., Kersters, K. \& Van Montagu, M. (1990). Identification and plant interaction of a Phyllobacterium sp., a predominant rhizobacterium of young sugar beet plants. Appl Environ Microbiol 56, 1093-1102.

Lanyi, B. (1987). Classical and rapid identification methods for medically important bacteria. Methods Microbiol 19, 1-67.

Ludwig, W., Strunk, O., Westram, R. \& 29 other authors (2004). ARB: a software environment for sequence data. Nucleic Acids Res 32, 1363-1371.

Marmur, J. (1961). A procedure for the isolation of deoxyribonucleic acid from microorganisms. J Mol Biol 3, 208-218.

Mergaert, J., Cnockaert, M. C. \& Swings, J. (2002). Phyllobacterium myrsinacearum (subjective synonym Phyllobacterium rubiacearum) emend. Int J Syst Evol Microbiol 52, 1821-1823.

Rosselló-Mora, R. \& Amann, R. (2001). The species concept for prokaryotes. FEMS Microbiol Rev 25, 39-67.

Skerman, V. B. D., McGowan, V. \& Sneath, P. H. A. (1980). Approved lists of bacterial names. Int J Syst Bacteriol 30, 225-420.

Smibert, R. M. \& Krieg, N. R. (1994). Phenotypic characterization. Methods Gen Mol Bacteriol 25, 607-654.

Soto-Hernandez, J. L., Nunley, D., Holtsclaw-Berk, S. \& Berk, S. L. (1988). Selective medium with DNase test agar and a modified toluidine blue $\mathrm{O}$ technique for primary isolation of Branhamella catarrhalis in sputum. J Clin Microbiol 26, 405-408.

Stackebrandt, E., Frederiksen, W., Garrity, G. M. \& 10 other authors (2002). Report of the ad hoc committee for the re-evaluation of the species definition in bacteriology. Int J Syst Evol Microbiol 52, 1043-1047.

Strimmer, K. \& von Haeseler, A. (1996). Quartet puzzling: a quartet maximum-likelihood method for reconstructing tree topologies. Mol Biol Evol 13, 964-969.

Ziemke, F., Höfle, M. G., Lalucat, J. \& Rosselló-Mora, R. (1998). Reclassification of Shewanella putrefaciens Owen's genomic group II as Shewanella baltica sp. nov. Int J Syst Bacteriol 48, 179-186. 